\title{
Identification of Goat Skin and Pig Skin as the Raw Material of Rambak Using PCR-RFLP Method
}

\author{
D. Triasih ${ }^{1 *}, Y$. Erwanto ${ }^{2}$, and N. A. Fitrianto ${ }^{2}$ \\ ${ }^{1}$ Livestock Products Processing Technology, Banyuwangi State Polytechnic, \\ ${ }^{2}$ Departement of Animal Products Technology Faculty of Animal Science, Gadjah Mada University, \\ *Corresponding e-mail: triasihdyah@gmail.com
}

\begin{abstract}
The aim of this research was to detect the skin which comes from goat and pig using PCR-RFLP method so the raw material used in rambak product was discovered. The comparison of combination between goat and pig skin was 100, 75:25, 91:9, 94:6, 97:3, and 99:1. PCR-RFLP uses the universal primary from from mitochondria cytochrome $\mathrm{b}$ gen which results in the length of fragment of $359 \mathrm{bp}$. The restriction enzyme used in the DNA cut is BamHI enzyme and BseDI enzyme. The result of the research showed that seven samples have been successfully isolated perfectly so the total bands of genomic DNA have been obtained which is clearly seen and amplification with target of cytochrome b gen results in PCR product of goat and pig of $359 \mathrm{bp}$. The digestion's result using BamHI enzyme gets fragment size on $359 \mathrm{bp}$ in length on goat samples and length of fragment size of 359, 244, and $115 b p$ on samples which contain pig. The digestion results of using BseDI results in fragment size of $359 b p$ in length on goat samples and the fragment size of 359, 228, and $131 b p$ in length on samples which contain pig. The conclusion of the research is PCR-RFLP using BamHI enzyme and BseDI enzyme can be used to detect the types of pig skin, but can't be used to detect the goat skin.
\end{abstract}

Key words: skin, DNA mitochondria, cytochrome $b$ gen, polymerase chain reaction, restriction of fragment length polymorphism

\section{INTRODUCTION}

Food products in human's life were the most important thing to fulfill the nutrient needed by the body. The decent food product which gets to the requirement of being consumer is the healthy, nutritious, and safe food product. This fits the explanation of regulations Number 18 Year 2012 about the food which becomes the most basic need of human and the fulfillment is the part of every Indonesians citizens' rights. Food has to be always be enough, safe, qualified, nutritious, and various with affordable prize for people's purchasing ability and not against their purchasing ability as well as their religion, faith, and culture. In these some couples years, the producers who work in food companies have started increasing the technology of producing animal feed ingredients, one of which using skin that becomes the side result of animal slaughtering.

Skin was used as the food material because it contains high nutrient. The skin nutrient content was protein, calorie, calcium, phosphor, fat, vitamin A, and vitamin B1. The fresh skin content was generally structured from $65 \%$ water, $1.5 \%$ fat, $0.5 \%$ mineral, and $33 \%$ protein. The specialty of goat skin and pig skin was that it is possible to be processed into various skin products such as food and also some other things like leather shoes and leather bag (Sarkar, 1982). According to Fauziah (2016), PCR technology using D-Loop mitochondria has high sensitivity in detecting pork DNA with rambak cracker samples so that the PCR method is proposed as an analysis in monitoring meat products.

The type of skin that is usually used for processing rambak is cow's and buffalo's skin. However, due to the technology development and innovation, people have started making rambak out of goat and pig skin as well as any other skin. After the PCR-RFLP is found, the identification process food basic ingredients especially the food, which is made out of skin can be detected.

The main problem faced in method with DNA basis is the ease of DNA isolation process to get the complete genomic DNA since the DNA isolation is the important factor in the success of next process. DNA which has good quality is the requirement which has to be fulfilled in molecular research. The analysis of PCR continued to RFLP is the step to ease the identification of skin types used in rambak raw material. Consequently, there has to be a basic research to figure out the species from various fresh skin types especially goat and pig skin in 
order to identify the type of skin used in rambak product.

\section{MATERIAL AND METHODS}

The materials used as samples in this research are corned goat skin and pig skin in fresh skin quality. The supplement materials are buffer TEN/STE (10 mMTrisHCl, $1 \mathrm{mM}$ EDTA, $0,1 \mathrm{M} \mathrm{NaCl}$ ) (Merc), solution of Sodium dodecyl sulfate (SDS) $10 \%$ (Merc), solution of proteinase $K$ (Thermo Scientific), solution of $\mathrm{NaCl} 5 \mathrm{M}$ (Merc), Solution of Phenol (Merc), solution of Chloroform Isoamyl Alcohol (CIAA) (Merc), solution of Ethanol 100\% (Ethanol absolut), solution of Ethanol 70\% (Merc), solution of Tris EDTA (TE), Maxima Hot Start Green PCR Master Mix (Thermo Scientific), tangobuffer, BamHIbuffer, BamHI enzyme (Thermo Scientific), BseDI enzyme (Thermo Scientific), aquabidest, buffer of Tris Boric EDTA (TBE) 1X, Ethidium bromide, agarose (Thermo Scientific), DNA ladder (Thermo Scientific), and Loading dye (Thermo Scientific).

The tools used in this research are mortar, Refrigerated Microcentrifuge $(>10.000 \mathrm{x}$ g), eppendorf tube of $0.2 \mathrm{ml}$, Eppendorf tube of $0.5 \mathrm{ml}$ or $1.5 \mathrm{ml}$, the sample storage box, eppendorf tube shelf, water bath, vortex mixer, pipettor or pipetman, pipette (white, blue, and yellow), hand glove, masker, autoclave, nano drop spectrophotometer, Thermal cycler machine, horizontal agarose gel electrophoresis apparatus (MUPID), Well-forming combs, power supply, micorwafe or hotplate, UV-trans illuminator, and digital camera.

\section{Sample preparation}

The fresh goat skin and pig skin are bought from RPH Giwangan, Yogyakarta. The skin is cut into pieces separately to avoid contamination. After that the skin is packed and stored on $-20^{\circ} \mathrm{C}$ temperature until it is used for research. Comparison between goat skin and pig skin sample was showed in Table 1.

\section{Primary Design}

The primary universal used is cytochrome bgen according to the publication of Kocher et al. (1989) with the alkaline composition as follows: Forward: L14841 (5'CCA TCCAAC ATC TCA GCA TGA TGAAA3') Reverse: H15194 (5'-GCC CCT CAG AAT GAT ATT TGT CCT CA-3') and using restriction enzyme of BamHI and BseDI to cut the DNA from cytochrome bgen.

Table 1.Comparison between goat skin and pig skin sample

\begin{tabular}{lll}
\hline No. & Sampel & $\begin{array}{l}\text { Skin Percentage } \\
\text { Comparison }\end{array}$ \\
\hline 1. & Goat Skin & $100 \%$ \\
2. & Pig Skin & $100 \%$ \\
3. & Goat Skin : Pig Skin & $75 \%: 25 \%$ \\
4. & Goat Skin : Pig Skin & $91 \%: 9 \%$ \\
5. & Goat Skin : Pig Skin & $94 \%: 9 \%$ \\
6. & Goat Skin : Pig Skin & $97 \%: 3 \%$ \\
7. & Goat Skin : Pig Skin & $99 \%: 1 \%$ \\
\hline
\end{tabular}

\section{DNA Isolation}

The DNA extraction and purification method uses the procedure of Sambrooket al. (1989) which has been modified, which is the $\pm 30 \mathrm{mg}$ are cut and crushedby mortar until smooth. Then, they are entered into a tube with capacity of $1.5 \mathrm{ml}$. The extraction is started by adding $500 \mu$ lbuffer TEN/STE. After that, those are being under vortex as well as the $30 \mu \mathrm{l}$ proteinase $K, 50 \mu \mathrm{l} 10 \% \mathrm{SDS}$, then being incubated into the water bath in $42^{\circ} \mathrm{C}$ temperature for $18-19$ hours. There are $50 \mu \mathrm{l}$ $5 \mathrm{M} \mathrm{NaCl}, 400 \mu \mathrm{l}$ phenol, $400 \mu \mathrm{l}$ CIAA being incubated into waterbath in $37^{\circ} \mathrm{C}$ temperature for 1 hour. Then the centrifugation of $3.000 \mathrm{rpm}$ happens on $4^{\circ} \mathrm{C}$ temperature for 5 minutes. The supernatant is moved to new tube by adding the $50 \quad \mu 1 \quad 5 \mathrm{M}$ NaCland $800 \mu \mathrm{l}$ absolute ethanol. Those are shaken by hands until white threads are formed. The incubation takes place in freezer for 1 hour with $-20^{\circ} \mathrm{C}$ temperature. The centrifugation of $8.000 \mathrm{rpm}$ exists for 5 minutes, and thenthe liquid is thrown away. $1000 \mu \mathrm{l}$ ethanol $70 \%$ is added. Another centrifugation of $8000 \mathrm{rpm}$ takes place in $4^{\circ} \mathrm{C}$ for 5 minutes. The liquid is thrown away and leaked until there is no liquid left. After then, it is dried using densicator for \pm 19 hours until it is completely dried. Lastly, it is added with $50 \mu \mathrm{TE}$ and stored in $-20^{\circ} \mathrm{C}$ temperature until it is used again. Then $12 \mu 1$ of each sample is taken from DNA isolation and added with $3 \mu$ l loading dye then being under electrophoresis on 100 volts of $2 \%$ agarose gel for 30 minutes in TBE 1Xbuffer. 100 bpmarkers (thermo scientific) is used as DNA ladder.

\section{Amplication of PCR cytochrome b}

Amplification of cyt $b$ gen is done in final volume of $25 \mu \mathrm{l}$ which contains $\mathrm{dH}_{2} \mathrm{O} 2$ 
$\mu 1$, Green PCR master mix $20 \mu \mathrm{l}(2 \mathrm{X}$ hot start PCR buffer, $400 \mu \mathrm{M}$ dATP, $400 \mu \mathrm{M}$ dGTP, 400 $\mu \mathrm{M}$ dCTP, $400 \mu \mathrm{M}$ dTTP, and $4 \mathrm{mM} \mathrm{Mg}^{2+}$ ) (Thermo Scientific), primary universal reverse 1 $\mu 1 \quad(20$ pmol) (Thermo Scientific), primary universal forward $1 \mu 1 \quad(20$ pmol) (Thermo Scientific) and $1 \mu 1$ of extraction result of DNA. Amplification is done by using these programs: Amplification is conducted with these programs: pre denaturation $94^{\circ} \mathrm{C}$ for 2 minutes, denaturation $95^{\circ} \mathrm{C}$ for 36 seconds, annealing $53^{\circ} \mathrm{C}$ for 72 seconds, extension $72^{\circ} \mathrm{C}$ for 84 seconds, with PCR cycle is repeated for 35 times. When the post extension $72^{\circ} \mathrm{C}$ has been for 3 minutes, the temperature is decreased to $30^{\circ} \mathrm{C}$. After that, $8 \mu 1$ of each sample is taken from PCR result added by $2 \mu \mathrm{l}$ loading dye in electrophoresis on 100 volts of $2 \%$ agarose gel for 30 minutes in TBE $1 x$ buffer. A $100 \mathrm{bp}$ marker (Thermo Scientific) is used as DNA ladder. The PCR result is stored on $-20^{\circ} \mathrm{C}$ temperature until it is used for the next analysis.

\section{RFLP Analysis}

The next phase after PCR is the RFLP analysis using two enzymes, those of which are restriction BseDI enzyme (Thermo Scientific) (which is used for $10 \mu \mathrm{l}$ of PCR products for 30 final volumes of digestion combination consisting of $18 \mu \mathrm{ldH} 2 \mathrm{O}, 2 \mu \mathrm{l} 10 \mathrm{x}$ buffer tango (10 mMTris- $\mathrm{HCl}, 100 \mathrm{mMKCl}, 1 \mathrm{mM}$ DTT, 1 $\mathrm{mM}$ EDTA, 0,2 $\mathrm{mg} / \mathrm{ml} \mathrm{BSA}$, and 50\% gliserol)) and being incubated in $55^{\circ} \mathrm{C}$ for \pm 5 hours. BamHI restriction enzyme (Thermo Scientific) (which is used for $10 \mu \mathrm{l}$ of PCR products for 30 final volumes of digestion combination consisting of $18 \mu \mathrm{ldH} 2 \mathrm{O}, 2 \mu \mathrm{l} 10 \mathrm{x}$ buffer BamHI $\left(10\right.$ mMTris- $\mathrm{HCl}\left(\mathrm{pH} \mathrm{7,4}\right.$ padasuhu $\left.25^{\circ} \mathrm{C}\right), 200$ $\mathrm{mM} \mathrm{NaCl}, 1 \mathrm{mM}$ DTT, 0,1 mM EDTA, 0,15\% Triton X-100, $0,2 \mathrm{mg} / \mathrm{ml}$ BSA dan $50 \%$ glycerol) and being incubated in $37^{\circ} \mathrm{C}$ for \pm 4 hours. $12 \mu 1$ is taken from each digestion sample and added by $3 \mu \mathrm{l}$ loading dye which is being under electrophoresis on 100 volts of $3 \%$ agarose gel for 30 minutes in TBE 1X buffer. $100 \mathrm{bp}$ marker (Thermo scientific) is used as DNA ladder.

\section{RESULT AND DISCUSSIONS}

\section{DNA Isolation}

DNA isolation uses Sambrook method which has been modified on fresh goat and pig skin samples which result in DNA isolate with good quality. The critical point of DNA isolation modification needs incubation time for $\pm 18-19$ hours in $42^{\circ} \mathrm{C}$ temperature so it can digest the DNA perfectly and decrease the contaminant in resulted DNA. Result isolation was showed in figure 1 .

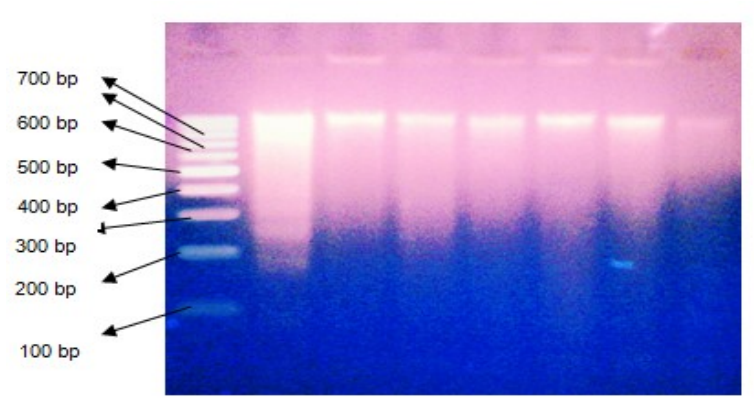

Figure 1. Result of Skin DNA Isolation line 1 : goat samples $100 \%$, line 2: Pig samples $100 \%$, line 3: Goat: Pig $=75: 25$, line 4: Goat : Pig $=91: 9$, line 5: Goat $:$ Pig $=94: 6$, line 6: Goat $:$ Pig $=96: 9$, line 7: Goat : Pig $=99: 1,(\mathrm{M}):$ marker 100 bp DNA ladder (Thermo Scientific).

Figure 1 shows that by using the Sambrook method which has been modified, there will be seen bright and clear DNA bands. This thing shows the DNA which has been successfully isolated perfectly, but there is also smear which marks DNA that has not been isolated perfectly. Smear appears due to the DNA purified phase which can result in the DNA that is free from dirt while the DNA cleaning phase with the addition of ethanol can precipitate the DNA because nucleate acid will precipitate and be difficult to be soluble into ethanol, while the dirt can be soluble into ethanol so the DNA quality result in the electrophoresis will show the existence of smear. The thickness of different band of every sample shows the difference of DNA concentration. Besides, it is influenced by the thickness and thinness of DNA bands formed which show the content or number of DNA that have same molecule weight on the same band position. Even though the sample is not isolated perfectly, through the existence of DNA from samples the isolation result of DNA mitochondria can be used as amplication template of cytochrome $\mathrm{b}$ at PCR process. This result is based on research of Ong et al. (2007) that bands with high intention while being in electrophoresis proves that DNA has been enough extracted and has good quality to be used of PCR product of mitochondria cyt $b$. 


\section{Amplification of Cytochrome BGen}

The reduplication of DNA chains using Polymerase Chain Reaction (PCR) technique on DNA template is obtained from isolation result. The PCR program used has 35 cycles consisting of pre denaturation phase with $95^{\circ} \mathrm{C}$ temperature for 2 minutes, denaturation of $95^{\circ} \mathrm{C}$ temperature for 36 seconds, annealing of $53^{\circ} \mathrm{C}$ temperature for 1 minute and 13 seconds, extension of $72^{\circ} \mathrm{C}$ temperature for 1 minute and 24 seconds and post extension of $72{ }^{\circ} \mathrm{C}$ temperature for 3 seconds. The PCR cycles are 35 times. This is done in order to obtain molecules of double DNA chains which are the result of polymeration in large numbers comparing to the total of DNA used.

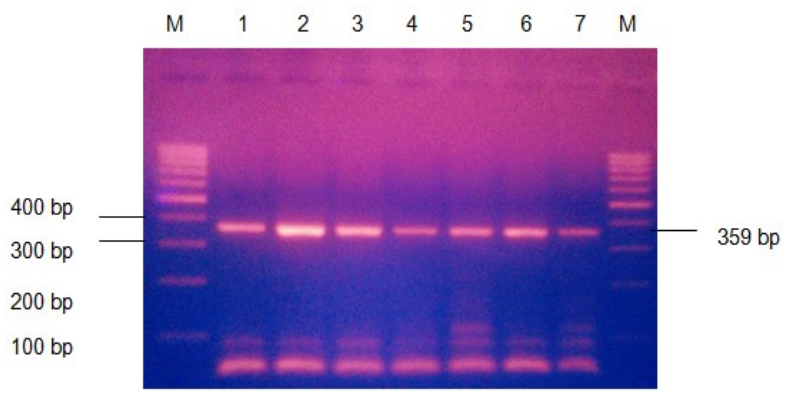

Figure 2. Amplification result of cyt $\mathrm{b}$ gen. Line 1: goat samples $100 \%$, line 2: pig samples $100 \%$, line 3: Goat : Pig $=75$ : 25, line 4: Goat : Pig =91: 9, line 5: Goat $:$ Pig $=94: 6$, line $6:$ Goat $:$ Pig $=$ $96: 9$, line 7: Goat : Pig $=99: 1,(\mathrm{M})$ : 100 bpmarker DNA ladder (Thermo Scientific).

The figure 2 of this research shows that the DNA amplification of isolation result uses primary couple Forward: L14841 (5'-CCA TCC AAC ATC TCA GCA TGA TGA AA-3') and Reverse: H15194 (5'-GCC CCT CAG AAT GAT ATT TGT CCT CA-3'). These primary things result in DNA fragment size of $359 \mathrm{bp}$. This shows that the sample are used in the next analysis step. According to Watson et al. (2009) DNA polymerase with primary has function to start the synthesis from single chain. The primary used completes the target DNA from 5' to 3 '. The speed of arranging the DNA depends on the DNA molecule target which is wished.

Based on the optimization result of PCR towards the skin samples as seen in above figures, it is the electrophoresis result with $2 \%$ agarose. The template sample of DNA has been successfully amplificated by forming the DNA bands with fragment size of $359 \mathrm{bp}$. This fits the research of Erwanto et al (2011) which results in DNA fragment size of $359 \mathrm{bp}$ on cyt b out of pork, and Jonasi (2006) also gets cyt b out of chicken with 359 bp fragment size. Under the smear, there is a very bright band (with high intention). The band which is in this part is the RNA contaminant. This is due to the addition of rnaAse during the DNA isolation time. The use of universal primary indeed strengthens the pig's DNA fragment. The detection result with PCR of universal primary shows the specification and sensitivity in detecting the pig skin as well as predicting the number of pig skins which have been mixed.

\section{Restriction Fragment Length Polymorphism (RFLP) by Using Bam HI Enzyme and Bse DI Enzyme}

Restriction Fragment Length Polymorphism (RFLP) is a technique used to identify the variety of genetics between species or interspecies. The use of restriction enzymes to identify the difference of genetics from various species can result in different fragments (Erwanto et al., 2011). The type of PCR-RFLP has a system to multiply a certain DNA fragment to figure out the difference of a fragmen restriction site on fragment among individuals in certain population or family (Grifiiths et al., 1998).

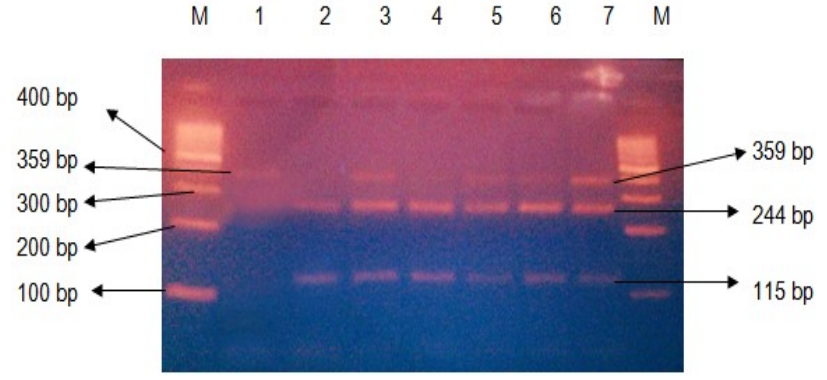

Figure 3. Digestion result with restriction enzyme of BamHI in 4 hours at $37^{\circ} \mathrm{C}$ temperature, $3.0 \%$ of electrophoresis. Line 1: goat samples $100 \%$, line 2: pig samples $100 \%$, line 3: Goat : Pig $=75: 25$, line 4: Goat : Pig = 91: 9, line 5: Goat : Pig $=94: 6$, line 6: Goat : Pig $=96: 9$, line 7:Goat $:$ Pig $=$ 99 : 1, (M): marker 100 bp DNA ladder (Thermo Scientific).

Figure 3 shows the RFLP result of goat skin and pig skin samples by using $37^{\circ} \mathrm{C}$ temperature and 4 hours of incubation time with 
$3 \%$ of agarose resulting in some fragment pieces in one line. There is one band on goat skin sample (line 1) with the length of fragment size is $359 \mathrm{bp}$. On the pig skin (line 2), there are two bands with the length of fragment is 244 and 115 $\mathrm{bp}$ and also for the combination of goat skin and pig skin (line 3, 4, 5, 6, and 7) there are length of fragments which are 359, 244, and $115 \mathrm{bp}$. However, the template of goat skin DNA on the combination is uncut. The cut part is only the DNA of pig skin.

This shows the success of pig skin identification. The success of RFLP is very influential for the DNA isolation result. The length of Bam HI enzyme piece is the same as the research Trijoko et al. (2012) who does RFLP analysis by using chicken nugget, pork nugget, and the combination chicken and pork nugget samples which results in the length of fragment size of 244 and $115 \mathrm{bp}$. While the research of Erwanto et al. (2012) used the sample of meatballs made from beef, chicken, pork and the combination of beef, chicken, and pork which result in the length of fragment size of 245 and $114 \mathrm{bp}$.

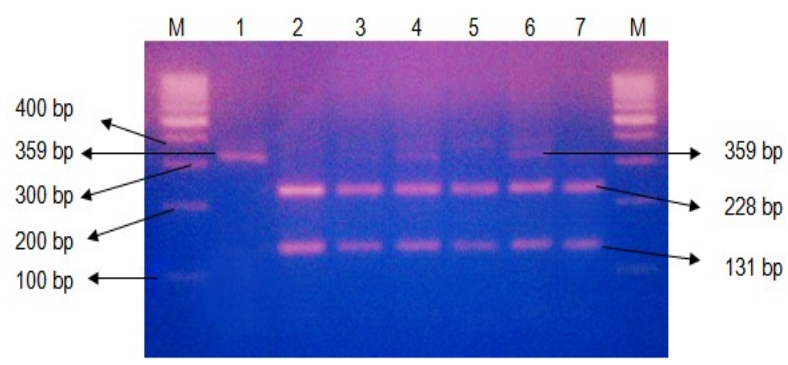

Figure 4. Digestion result with restriction enzyme of BseDI in 5 hours at $55^{\circ}$ Ctemperature, $\quad 3.0 \% \quad$ of electrophoresis. Line 1: goat samples $100 \%$, line 2: pig samples $100 \%$, line 3 : Goat : Pig $=75: 25$, line $4:$ Goat $:$ Pig $=91: 9$, line $5:$ Goat $:$ Pig $=94: 6$, line 6: Goat : Pig $=96: 9$, line 7:Goat : Pig $=99: 1,(\mathrm{M}): 100$ bpmarker DNA ladder (Thermo Scientific).

Figure 4 shows the result of goat skin sample and pig skin sample with the temperature of $55^{\circ} \mathrm{C}$ with incubation time of \pm 5 hours and with the use 3\% agarose resulting in some pieces of DNA fragments in one line. There is one band on goat skin sample (line 1) with the size of 359 . On pig skin (line 2), there are 2 bands which 228 and 121 as well as the combination of goat skin and pig skin (line 3, 4, 5, 6, and 7) having three bands with the size of 359,228 , and 131. But the DNA template of goat skin on the combination is not cut, the cut part is the DNA template of pig skin. This fits the result of research carried out by Fitrianingsih (213) who uses beef and pork samples to obtain the length of fragment pieces which are 228 and $131 \mathrm{bp}$ and the research conducted by Erwanto et al. (2012), Trijoko et al. (2012) and Murugaiah (2009) who use the identification of pork in every food processing which result in length of fragments of 228 and $131 \mathrm{bp}$ on pork amplicon. This shows the success of pig skin identification. The good quality of DNA is very influential towards the success level of RFLP, the phase for reaching the good quality of DNA started from DNA isolation step.

\section{CONCLUSION}

The method of PCR-RFLP using the enzyme restriction of BamHI and restriction enzyme of BseDI on the result of mitochondria amplicon of cytochrome bgen can be used to identify the raw skin material of processing rambak. The use universal primary on cytochrome bgen results in the length of fragment size which is $\pm 359 \mathrm{bp}$. The DNA template of goat skin can be cut using BamHI and BseDI enzymes but the DNA template of pig skin cannot be cut.

\section{REFERENCE}

Erwanto, Y., M.Z. Abidin, A. Rohman and Sismindari. 2011. PCR-RFLP using BseDI enzyme for pork authentication in sausage and nugget products. Media Peternakan. 13(1): 14-18.

Erwanto, Y., M.Z. Abidin, Sismindari, and A. Rohman. 2012. Pig species identification in meatballs using polymerase chain reaction-restriction fragment length polymorphism for halal authentication. International Food Research Journal 19:901-906.

Fauziah, A.R. 2016. Identification of skin contaminants pork on rambak crackers with method real-time polymerase chain reaction using d-loop 22 'mitochondrial primer for Master Thesis, Universitas Gadjah Mada, Yogyakarta. 
Fitrianingsih. 2013. Optimization of DNA isolation on processed meat as the basis for detection of porcine contamination for master thesis, University of GadjahMada, Yogyakarta.

Grifiiths, A.J.F., J.H. Miller, D.T. Suzuki, R.C. Lewontin and W.M Gelbert. 1998. An Introduction to Genetic Analysis. Six Edition. W.H. Freeman and Company. New York.

Jonasi, A. 2006. Species specific detection of meat by polymerase chain reaction techniques for master thesis, University Corvinus, Budapest.

Kocher, Z.,A. S.V. Thomas, S. Meyer, Edwards and F.X. Paabo. 1989. Dynamic of mitochondrial DNA evolution in animal: amplifications and secuencing with conversed primers. Proceedings of the National Academy of Science of the USA. 86: 6169-6200.

Murugaiah, C., Z.M. Noor, M. Mastakim, L.M., Bilung, J. Selamat and S. Radu. 2009. Meat species identification and halal authentication analysis using mitochondrial DNA. Meat Sci. 83: 57-61.

Ong S.B., M.I. Zuraini, M. G. Jurin, Y.H. Cheah, R. Tunung, L.C. Chai, Y. Haryani, F.M. Ghazali and R. Son. 2007. Meat moleculer detection sensitivity of PCRRFLP in species differentiation of meat from animal origin. ASEAN Food Journal 14: 51-59.

Sambrook, J., E.F. Fritch and T. Maniatis. 1989. Molecular Cloning, A. Laboratory Manual. $2^{\text {nd }}$ ed. Cold SpringHarbour Lab. Press, New York.

Sarkar, K.T. 1982. Processing of goat skins for commercial leathers.Published by K.T. Sarkar. Madras, India. pp. 1-5.

Trijoko, R., W. Cahyaningtyas, Surajiman, Istini, and D. Pranowo. 2012. Validation of PCR-RFLP testing method to detect porcine contamination in chicken nugget. Indo. J. Chem. 12: 302-307.

Watson, D., M. James, J. Gilman, Witkowski and M. Zoller. 1992. Recombinan DNA. $2^{\text {nd }}$ ed. United States of America. 